\title{
Skrining dan Identifikasi Bakteri Pektinolitik Endosimbion dalam Sistem Pencernaan Serangga Penggerek Kopi (Hypothenemus hampei Ferr.)
}

\author{
Gatot Kusiyanto $^{1)}$, Purwatiningsih' ${ }^{1)}$, Kahar Muzakhar ${ }^{1 *}$ \\ ${ }^{1)}$ Program Studi Magister Biologi, Fakultas Matematika dan Ilmu Pengetahuan Alam, Universitas Jember, Jl. \\ Kalimantan No. 37, Jember, Jawa Timur, Indonesia \\ ${ }^{*}$ Alamat korespondensi: kaharmzk@unej.ac.id
}

\begin{abstract}
ABSTRAK
Serangga Hypothenemus hampei memiliki kemampuan untuk menggerek biji kopi, dan digunakannya sebagai sumber makanan, tempat hidup dan siklus hidup. Aktivitas hidup dari $\boldsymbol{H}$. hampei menyebabkan rontoknya buah kopi dan penurunan kualitas serta kuantitas buah kopi hingga $40 \%$. Penelitian ini bertujuan untuk mendapatkan isolat bakteri pektinolitik yang memiliki toleransi tinggi terhadap lingkungan khususnya kafein, tanin dan polifenol. Prosedur penelitian terdiri dari tahap pembuatan media skrining bakteri pektinase, isolasi bakteri endosimbion dan identifikasi spesies serta fisiologi bakteri. Berdasarkan hasil identifikasi dan skrining bakteri pada sistem pencernaan $\boldsymbol{H}$. hampei didapatkan 15 isolat bakteri pektinolitik endosimbion. Hasil identifikasi tiga isolat terpilih diketahui bahwa isolat 2B termasuk golongan Enterobacter sp. atau Actinobacillus sp., isolat 31B masuk ke dalam Micrococcus sp. dan isolat 42B termasuk Chromobacterium sp. Penelitian ini berguna sebagai kajian untuk strategi penanganan hama serangga $H$. hampei dengan menghambat pertumbuhan bakteri pektinolitik.
\end{abstract}

Kata kunci: skrining, pektinolotik, Hypothenemus hampei, endosimbion

\section{Screening and Identification of Pectinolytic Endosymbiontic Bacteria in the Digestive System of Coffee Berry Borer (Hypothenemus hampei Ferr.)}

\author{
Gatot Kusiyanto $^{1)}$, Purwatiningsih ${ }^{1)}$, Kahar Muzakhar ${ }^{1)^{*}}$ \\ ${ }^{1)}$ Study Program of Biology Postgraduate, Faculty of Mathematics and Natural Sciences, University of Jember, \\ Kalimantan Street No. 37, Jember, East Java, Indonesia \\ ${ }^{*}$ Email: kaharmzk@unej.ac.id
}

\begin{abstract}
Hypothenemus hampei insects have the ability to drill coffee beans, and then it is used as food sources, living places and life cycles. The life activity of $\mathrm{H}$. hampei causes the fruit fall and decreased the quality and quantity of coffee fruit up to $40 \%$. This study aimed to obtain isolates of pectinolytic bacteria that tolerant to the environment, especially caffeine, tannins and polyphenols. The research procedure consisted of the making of screening media of pectinase bacteria, the isolation and identification of bacterial species as well as its physiology. Based on the results of identification and screening of bacteria in the digestive system $\mathrm{H}$. Hampei, it was obtained 15 isolates of the bacteria pectinolytic endosymbiont. Three isolate obtained were identified which were $2 \mathrm{~B}$ isolate included the Enterobacter sp. or Actinobacillus sp., 31B isolate was similar to Micrococcus sp., and 42B isolate was close to Chromobacterium sp. This research was useful as a study for insect pest management strategy of $\boldsymbol{H}$. hampei by inhibiting the growth of pectinolytic bacteria.
\end{abstract}

Keywords: screening, pectynolitic, Hypothenemus hampei, endosymbiont

\section{PENDAHULUAN}

Kopi (Coffea sp.) merupakan komoditas perkebunan utama yang ada di Indonesia. Produksi kopi di Indonesia pada tahun 2012 mencapai 748 ribu ton yang terdiri dari kopi robusta (C. Canephora) sebesar 601.000 ton $(80,4 \%)$ dan kopi arabika (C. Arabica) sebesar 147.000 ton $(19,6 \%)$ atau sekitar $6,6 \%$ produksi kopi dunia, sehingga Indonesia berada di posisi ketiga sebagai produsen kopi terbesar setelah Brazil dan Vietnam [1]. Pada 
saat ini, produksi kopi di Indonesia terus mengalami penurunan dari tahun ke tahun selanjutnya yaitu 740.000 ton (2013), 712.000 ton (2014), 550.000 ton (2015), 664.000 ton (2016), 669.000 ton (2017) hingga pada tahun 2018 hanya mencapai 674.000 ton dan pada akhirnya Indonesia berada di posisi keempat produsen kopi setelah Kolombia [2]. Penyebab utama penurunan produksi kopi di Indonesia adalah adanya hama pada kopi yaitu serangga penggerek kopi Hyphotenemus hampei Ferr.

Serangga $H$. hampei memiliki kemampuan untuk menggerek biji kopi, dan digunakannya sebagai sumber makanan, tempat hidup dan siklus hidup. Aktivitas hidup dimulai dari larva $H$. hampei yang berada di dalam biji kopi, memakan biji kopi sampai dewasa, sehingga seluruh siklus hidupnya ada di dalam biji kopi. Aktivitas hidup dari $H$. hampei menyebabkan rontoknya buah kopi dan penurunan kualitas serta kuantitas buah kopi hingga $40 \%$ [3]. Siklus hidup dari H. hampei yang berada di dalam biji kopi menyebabkan sulitnya penanganan hama tersebut. Serangga ini mampu bertahan hidup walaupun pada buah kopi mengandung kadar kafein, polifenol dan tannin tinggi yang bersifat toksik terhadap serangga tersebut [4].

Siklus hidup $H$. hampei yang dominan berada pada substrat ekstrem yaitu biji kopi menunjukkan bahwa serangga ini memiliki kemampuan adaptasi dan toleransi yang tinggi terhadap kondisi lingkungan pada biji kopi. Kemampuan untuk hidup pada biji kopi tersebut disebabkan karena adanya bakteri endosimbion pada saluran pencernaan $H$. hampei. Bakteri endosimbion pada serangga $H$. hampei berfungsi untuk membantu menyediakan nutrisi, meningkatkan toleransi terhadap lingkungan dan resistensi terhadap parasit [5]. Pada alat pencernaan H. hampei terdapat bakteri Pseudomonas flavus yang membantu mendegradasi kafein pada biji kopi [6]. Namun selain bakteri endosimbion yang membantu untuk mendegradasi kafein, serangga $H$. hampei juga memerlukan sumber karbon sederhana untuk metabolismenya. Sumber karbon sederhana didapat dengan memecah substrat polisakarida kompleks menjadi monomer sederhana yang bisa diserap oleh serangga. Pada biji kopi, terdapat kandungan $\mathrm{C}$ yang cukup tinggi yang berasal dari polisakarida seperti selulosa dan pektin. Kandungan selulosa pada biji kopi robusta sebesar 32-42\%, pada biji kopi arabika sebesar
41-43\% sedangkan pektin pada kopi sebesar $2 \%[7]$.

Bakteri pektinolitik endosimbion pada $H$. hampei menghasilkan enzim pektinase yang mendegradasi pektin di dalam biji kopi. Dengan ditemukannya fenomena bakteri endosimbion di dalam alat pencernaan serangga hama, maka dapat digunakan untuk pengendalian populasi dari hama yaitu dengan pemutusan mekanisme rantai simbiosis yang ada di dalam alat pencernaan.

Sebagai tahap awal yang harus diteliti dan diketahui adalah melakukan identifikasi bakteri pektinolitik yang bersimbiosis di dalam alat pencernaan $H$. hampei. Tahap kedua adalah karakterisasi enzim pektinase yang dihasilkan oleh bakteri endosimbion dan analisis mekanisme aktivasi. Dengan diketahui mekanisme aktivasi dan penghambatan (blocking) aktivasi pektinase dalam alat pencernaan $H$. hampei akan menyebabkan metabolisme pencernaannya terganggu.

\section{METODE PENELITIAN}

Pembuatan media skrining bakteri peptinase. Langkah awal, Pembuatan pektin agar (pektin 0,5\%, $\mathrm{Na}_{2} \mathrm{HPO}_{4} 6 \mathrm{~g} / \mathrm{L} . \mathrm{KH}_{2} \mathrm{PO}_{4} 3$ $\mathrm{g} / \mathrm{L}, \mathrm{NaCL} 0,5 \mathrm{~g} / \mathrm{L}, \mathrm{MgSO}_{4} 0,2 \mathrm{~g} / \mathrm{L}, \mathrm{NH}_{4} \mathrm{Cl} 1$ $\mathrm{mg} / \mathrm{L}$, pepton $2 \mathrm{~g} / \mathrm{L}$, dan agar $17 \mathrm{~g} / \mathrm{L}$ ) dengan cara mencampurkan bahan-bahan pembuatan media agar pektin. Selanjutnya dilakukan sterilisasi. Setelahnya media pektin agar cair dituang ke dalam cawan petri, selanjutnya didiamkan sampai padat. 
Isolasi bakteri endosimbion. Serangga dewasa $H$. hampei pada kopi diseleksi dari serangga lain dan diambil 10 ekor. Sampel dimasukkan ke dalam tabung reaksi yang berisi alkohol $40 \%$ dengan garam fisiologis $0,9 \%$ (pengenceran $10^{-1}$ ) dihomogenasi menggunakan vorteks kemudian dilakukan pengenceran bertingkat sampai $10^{-10}$ dengan mengambil $1 \mathrm{ml}$ dari pengenceran sebelumnya. Kemudian suspensi diencerkan dengan $9 \mathrm{~mL}$ $\mathrm{NaCl} \quad 0,9 \%$ steril. Sebanyak $1 \mathrm{~mL}$ suspensi serangga dewasa diambil dari pengenceran $10^{-3}$ sampai $10^{-10}$, lalu ditumbuhkan pada media pektin agar. Kultur diinkubasi selama 24-48 jam pada suhu $37^{\circ} \mathrm{C}$. Koloni bakteri yang tumbuh kemudian dimurnikan dengan menginokulasikannya kembali pada media nutrient agar dalam cawan petri sampai didapatkan seluruh biakan tersebut benar-benar murni.

Identifikasi spesies dan fisiologi bakteri. Identifikasi secara makroskopis diawali dengan dilakukan pengujian zona bening dengan menggunakan larutan congo red $(0,1 \% \mathrm{w} / \mathrm{v})$ sebagai larutan penguji dan $\mathrm{NaCl} 1 \%$ sebagai larutan pencuci. Sebanyak 1 $\mathrm{ml}$ larutan congo red $(0,1 \% \mathrm{w} / \mathrm{v})$ sampai merata kemudian diinkubasi selama 15 menit pada suhu kamar. Kemudian sampel dicuci dengan menggunakan larutan $\mathrm{NaCl} 2 \mathrm{M}$ sebanyak dua kali. Kemudian diamati dan diukur zona bening yang terbentuk. Indeks aktivitas peptinase dapat diukur dengan menggunakan persamaan sebagai berikut [8]:

$$
\begin{aligned}
& \text { Indeks Aktivitas Enzim } \\
& =\frac{\text { diameter zona bening }(\mathrm{mm})}{\text { diameter koloni }(\mathrm{mm})}
\end{aligned}
$$

Pengamatan bakteri secara mikroskopik yang meliputi pewarnaan Gram, uji motilitas, pewarnaan endospora dan bentuk sel. Pengamatan dilakukan menggunakan mikroskop (Olympus CX 21) dengan perbesaran 1000 kali. Uji biokimia dilakukan dengan menginokulasikan bakteri ke dalam larutan yang masing-masing mengandung glukosa, sukrosa, laktosa, arabinosa, maltosa, dan mannitol. Setiap larutan mengandung BTB (Brom Timol Blue) sebagai indikator $\mathrm{pH}$ dan ditambahkan pepton sebagai sumber nitrogen, vitamin, dan mineral. Uji katalase dilakukan dengan menambahkan larutan $3 \% \mathrm{H}_{2} \mathrm{O}_{2}$ pada koloni bakteri. Kemudian pembentukan gelembung udara (positif) diamati yang terjadi pada koloni. Uji sitrat dilakukan untuk mengetahui kemampuan bakteri dalam memfermentasi sitrat.

\section{HASIL DAN PEMBAHASAN}

Isolasi dan skrining bakteri pektinolitik. Pada tahap awal kegiatan isolasi dan skrining bakteri yang terdapat pada alat pencernaan serangga $H$. hampei yang ditumbuhkan pada media Nutrient Agar (NA) didapatkan 48 isolat. Kemudian isolat tersebut ditumbuhkan pada media selektif pektin dan hanya ada 15 isolat mampu tumbuh yaitu $1 \mathrm{~A}$, 2B, 3A, 5A, 10B, 12A, 17A, 18A, 31B, 37A, $40 \mathrm{~A}, 42 \mathrm{~B}, 45 \mathrm{~B}, 47 \mathrm{~A}$, dan 48B. Isolat yang mampu membentuk zona bening ada 12 yaitu 2B, 5A, 10B, 12A, 17A, 18A, 31B, 37A, 40A, 42B, 47A, dan 48B.

Aktivitas pektinolitik dari isolat bakteri uji dilihat berdasarkan kemampuan membentuk zona bening di sekeliling koloni bakteri yang ditumbuhkan pada media pektin yang telah ditetesi larutan iodin $0,03 \%$. Fungsi dari larutan iodin $0,03 \%$ yaitu mempercepat deteksi dan penyebaran bakteri dalam kultur bakteri yang ditandai dengan zona bening yang terbentuk. Zona bening menunjukkan bahwa isolat bakteri menggunakan pektin pada media untuk pertumbuhan dan menyebabkan pektin di sekeliling koloni habis terpakai sehingga terbentuk zona bening. Zona bening pada media pektin terbentuk disekitar pertumbuhan koloni maupun hanya terbentuk pada area koloni itu sendiri [9]. Semakin besar indeks pektinase, maka semakin besar pula aktivitas pektinolitik yang dihasilkan [10].

Berdasarkan hasil pengukuran zona bening diperoleh isolat $2 \mathrm{~B}$ memiliki nilai indeks aktivitas pektinolitik yaitu 9,91, isolat 31B dengan nilai indeks aktivitas pektinolitik sebesar 5,56 dan isolat 42B memiliki nilai indeks aktivitas pektinolitik yaitu 5,47 (Tabel 1). Zona bening pada media pektin pada isolat 2B memiliki indeks aktivitas pektinolitik yang paling tinggi dibandingkan dengan dua isolat lainnya yaitu isolat $31 \mathrm{~B}$ dan isolat $42 \mathrm{~B}$, namun dalam hal ukuran koloni isolat $2 \mathrm{~B}$ memiliki diameter koloni paling kecil jika dibandingkan kedua isolat tersebut. Hal ini menunjukkan bahwa isolat $2 \mathrm{~B}$ memiliki pertumbuhan koloni yang lebih rendah dibandingkan dengan kedua isolat lainnya pada media pektin. Isolat yang memiliki zona bening yang luas tanpa diikuti 
oleh tingginya indeks zona bening cenderung akan memproduksi enzim dengan aktivitas yang lebih tinggi [11].

Tabel 1. Indeks aktivitas bakteri pektinolitik isolat uji

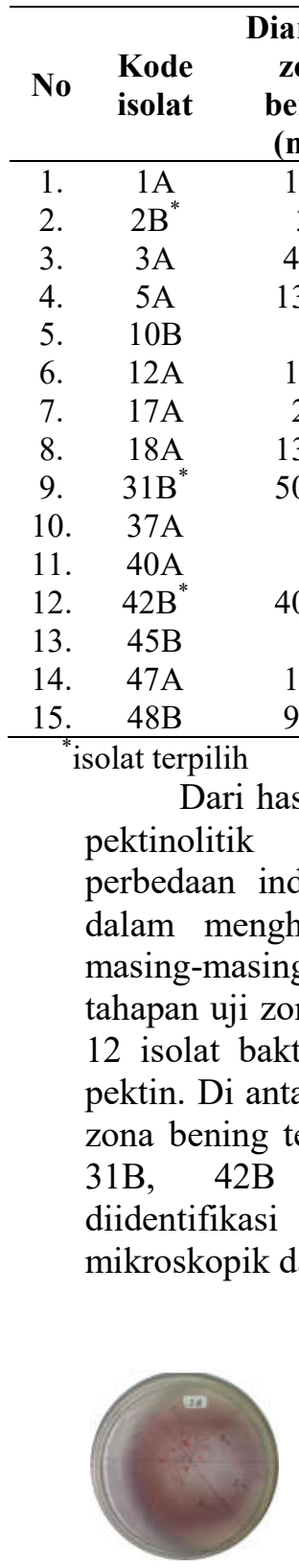

(a)

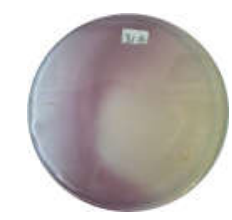

(b)

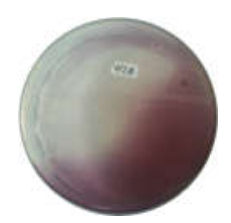

(c)
Gambar 1. Hasil uji aktivitas pektinolitik media pektin dengan pemberian larutan Iodine $0,03 \%$ (a) Isolat 2B; (b) Isolat 31B; (c) Isolat 42

1,59 0,80
Pengamatan secara makroskopik. Pengamatan makroskopik bakteri meliputi pengamatan morfologi dan pengujian zona bening $[12,13]$. Karakteristik koloni isolat 2B yaitu bentuk koloni bulat, elevasi koloni datar, tepi koloni penuh, dan berwarna putih susu. Isolat 31B dan 42B bentuk koloni memanjang, elevasi koloni datar, tepi koloni penuh dan warna koloni putih (Gambar 2).

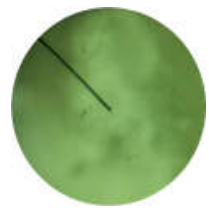

(a)

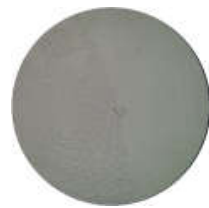

(b)

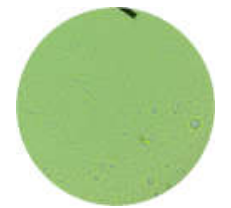

(c)
Gambar 2. Hasil pengamatan makroskopik (a) isolat 2B; (b) isolat 31B; (c) isolat $42 \mathrm{~B}$

Tabel 2. Pengamatan makroskopis bakteri pektinolitik

\begin{tabular}{|c|c|c|c|c|c|}
\hline \multirow{2}{*}{ No } & \multirow{2}{*}{$\begin{array}{l}\text { Kode } \\
\text { Isolat }\end{array}$} & \multicolumn{4}{|c|}{ Morfologi Koloni } \\
\hline & & Bentuk & Elevasi & Tepi & Warna \\
\hline 1 & $2 \mathrm{~B}$ & Bulat & Datar & Penuh & $\begin{array}{l}\text { Putih } \\
\text { susu }\end{array}$ \\
\hline 2 & 31B & Panjang & Datar & Penuh & $\begin{array}{l}\text { Putih } \\
\text { susu }\end{array}$ \\
\hline 3 & 42B & Panjang & Datar & Penuh & $\begin{array}{l}\text { Putih } \\
\text { susu }\end{array}$ \\
\hline
\end{tabular}

Pengamatan secara mikroskopik. Isolat $2 \mathrm{~B}$ dan $42 \mathrm{~B}$ adalah Gram negatif dan selnya berbentuk batang. Sedangkan isolat 31B adalah Gram positif dan selnya berbentuk bulat (Gambar 3 dan 4).

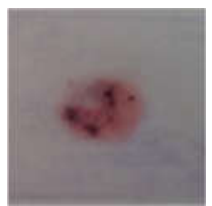

(a)

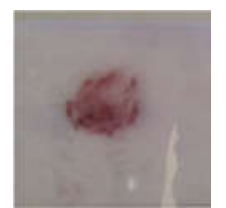

(b)

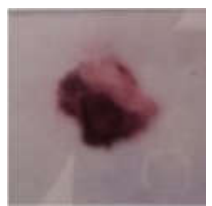

(c)
Gambar 3. Uji Gram (a) Isolat 2B; (b) Isolat 31B; (c) Isolat 42B

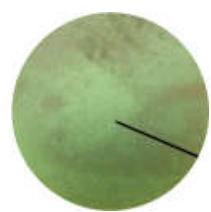

(a)

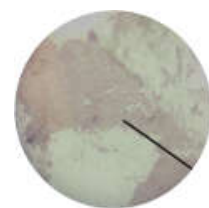

(b)

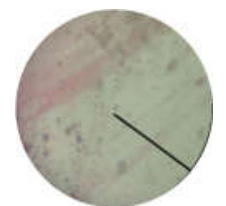

(c) 
Gambar 4. Hasil pewarnaan Gram (a) Isolat 2B; (b) Isolat 31B; (c) Isolat 42B

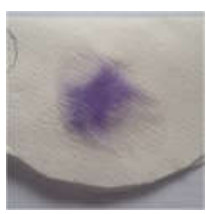

(a)

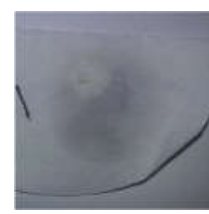

(b)

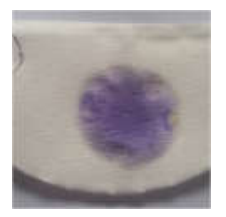

(c)
Gambar 5. Uji oksidase (a) Isolat 2B; (b) Isolat 31B; (c) Isolat 42B

Pada pewarnaan endospora semua isolat menunjukkan hasil NT (Not Testable). Spora bakteri adalah mekanisme bakteri yang sengaja diatur dalam upaya untuk mengamankan diri terhadap efek buruk dari lingkungan eksternal [14]. Pewarna Malachite Green dan Safranin dapat bekerja dengan baik pada bakteri karena alkalin (komponen chromophoric bermuatan positif), sedangkan sitoplasma bakteri bersifat basofilik, hal ini menyebabkan bakteri dapat menyerap zat warna dengan baik [15]. Uji motilitas digunakan untuk mengetahui pergerakan bakteri. Bakteri bergerak bebas memiliki flagel sebagai alat geraknya [16]. Hasil isolat uji 2B dan 42B memiliki hasil yang positif atau motil. Sedangkan isolat uji 31B memiliki hasil yang NT (Not Testable).

Uji biokimia. Uji biokimia meliputi uji katalase, uji karbohidrat, dan uji sitrat. Uji biokimia bakteri adalah suatu perlakuan untuk memudahkan identifikasi bakteri berdasarkan sifat-sifat fisiologinya [13].

Tabel 3. Hasil uji biokimia pada isolat uji

\begin{tabular}{ccccc}
\hline No & $\begin{array}{c}\text { Kode } \\
\text { Isolat }\end{array}$ & $\begin{array}{c}\text { Uji } \\
\text { Katalase }\end{array}$ & $\begin{array}{c}\text { Uji } \\
\text { Karbohidrat }\end{array}$ & $\begin{array}{c}\text { Uji } \\
\text { Sitrat }\end{array}$ \\
\hline 1. & $2 \mathrm{~B}$ & - & + & + \\
2. & $31 \mathrm{~B}$ & + & $\mathrm{NT}$ & + \\
3. & $42 \mathrm{~B}$ & + & + & + \\
\hline \multicolumn{4}{l}{ Keterangan: NT } & $=$ Not Testable (penelitian yang \\
\multicolumn{5}{l}{ tidak mungkin untuk dilakukan uji lanjutan) }
\end{tabular}

Uji katalase digunakan untuk mendeteksi bakteri yang mampu menghasilkan enzim katalase. Pembentukan gelembung saat penetesan larutan $\mathrm{H}_{2} \mathrm{O}_{2}$ menunjukkan hasil tes positif dengan adanya pelepasan oksigen [17]. Isolat $2 \mathrm{~B}$ adalah negatif, sedangkan uji pada isolat 31B dan 42B memiliki hasil positif terhadap uji katalase (Gambar 5).

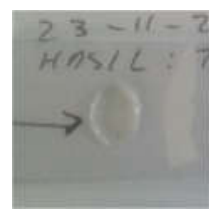

(a)

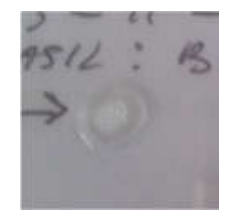

(b)

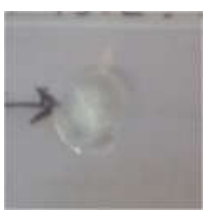

(c)
Gambar 5. Uji katalase (a) Isolat 2B; (b) Isolat 31B; (c) Isolat 42B

Uji karbohidrat dengan hasil positif diperoleh apabila terdapat perubahan warna dan terbentuknya gas yang menunjukkan bahwa terjadinya fementasi glukosa oleh bakteri. Fermentasi dapat menghasilkan berbagai senyawa asam seperti asam laktat dan propionat, ester, keton dan gas [18]. Dari hasil uji karbohidrat isolat $2 \mathrm{~B}$ dan $42 \mathrm{~B}$ hanya memiliki hasil positif pada uji glukosa, dan uji motilitas, laktosa, manitol dan sukrosa yang dikonfirmasi oleh perubahan warna dari merah ke warna kuning serta terbentuknya gelembung gas (Tabel 3).

Uji simon sitrat digunakan untuk melihat kemampuan bakteri enterik dapat memfermentasi sitrat menjadi sumber karbon. Mikroorganisme yang mampu menggunakan sitrat, akan menyebabkan kekurangan asam sehingga terjadi peningkatan $\mathrm{pH}$ dan terjadi perubahan warna dari hijau ke biru.

Identifikasi bakteri. Hasil pengamatan secara makroskopik, mikroskopik dan uji biokimia menunjukkan bahwa isolat 2B diketahui memiliki karakter yang sama dengan bakteri Enterobacteriaceae sp. atau Actinobacillus sp. Isolat 31B memiliki kesamaan dengan bakteri Micrococcus sp., sedangkan isolat 42B dengan bakteri Chromobacterium sp. (Tabel 4).

Tabel 4. Hasil identifikasi bakteri

\begin{tabular}{ccl}
\hline No & Kode Isolat & Jenis bakteri \\
\hline 1. & 2B & $\begin{array}{l}\text { Enterobacter } \mathrm{sp} . \\
\text { Actinobacillus } \mathrm{sp} .\end{array}$ \\
2. & 31B & Micrococcus $\mathrm{sp}$. \\
3. & 42B & Chromobacterium $\mathrm{sp}$. \\
\hline
\end{tabular}

Enterobacter sp. merupakan bakteri Gram negatif, bersifat fakultatif anaerobik, berbentuk batang dan bisa bergerak (motil). 
Bakteri berbentuk batang, dan panjangnya 1-5 $\mu \mathrm{m}$. Suhu pertumbuhan optimum $30-40^{\circ} \mathrm{C}$. Apabila Enterobacter sp. dikembangbiakkan pada media buatan, maka menunjukan aktivitas mengubah glukosa, selanjutnya membentuk asam dan gas. Bakteri ini dapat membentuk kapsul, sitrat, dan asetat yang dapat digunakan sebagai sumber karbon satusatunya [13].

Actinobacillus sp. merupakan bakteri berukuran sekitar $0,7 \times 1,0 \mu \mathrm{m}$. Bakteri ini dapat tumbuh soliter atau berkoloni, tidak bergerak, bersifat fakultatif anaerob dan kapnofilik [19]. Actinobacillus sp. memiliki fimbriae, membran sel yang mengandung protein dan mampu menghasilkan leukotoksin serta komponen seluler lain.

Micrococcus sp. merupakan bakteri dengan bentuk selnya bulat. Diameter koloni 1-2 $\mu \mathrm{m}$. Koloni muncul di atas permukaan media NA. Koloni berwarna kuning. Permukaan koloni mengkilat. Termasuk ke dalam bakteri Gram positif. Suhu pertumbuhan optimum $25-37^{\circ} \mathrm{C}$. Kebutuhan oksigen termasuk aerob dan anaerob. Termasuk pada bakteri yang tidak mampu bergerak. katalase, oksidase, dan produksi $\mathrm{H}_{2} \mathrm{~S}$ bersifat positif. Mampu tumbuh dengan baik pada media salinitas $7,5 \% \mathrm{NaCl}$.

Chromobacterium sp. merupakan bakteri fakultatif anaerob, Gram negatif dan berbentuk batang serta berpigmen ungu. Bakteri ini umumnya ditemukan di daerah beriklim tropis dan subtropis, pada air dan tanah, juga pada manusia dan hewan (bila terjadi infeksi) [20].

\section{KESIMPULAN}

Berdasarkan hasil identifikasi dan skrining bakteri pada sistem pencernaan $H$. hampei maka didapatkan 15 isolat bakteri pektinolitik endosimbion. Hasil identifikasi tiga isolat terpilih didapatkan bahwa isolat 2B termasuk golongan Enterobacter sp. atau Actinobacillus sp., isolat 31B termasuk ke dalam Micrococcus sp. dan isolat 42B termasuk Chromobacterium sp. Identifikasi spesies bakteri lebih lanjut menggunakan pendekatan molekuler perlu dilakukan.

\section{UCAPAN TERIMA KASIH}

Terima kasih disampaikan kepada Program Studi Magister Biologi Fakultas
MIPA Universitas Jember dan pihak yang telah membantu proses penelitian.

\section{DAFTAR PUSTAKA}

[1] Kementerian Perindustiran Republik Indonesia (2013) Produksi kopi nusantara ketiga terbesar di dunia. http://www.kemenperin.go.id/artikel 16611/Produksi-Kopi-Nusantara-KetigaTerbesar-Di-Dunia, Diakses pada 25 Agustus 2018.

[2] Indonesia Investments (2017) Kopi. https://www.indonesia-

investments.com/id

/bisnis/komoditas/kopi/item186, Diakses pada 25 Agustus 2018.

[3] Vega F, Jaramillo J, Castillo A, Infante F (2009) The coffee berry borer, Hypothenemus hampei (Ferrari) (Coleoptera: Curculionidae): A short review, with recent findings and future research directions. Terrestrial Arthropod Reviews 2 (2): 129:147.

[4] Navarro JAC, Vega FE, Karaoz U, Hao Z, Jenkins S, Lim HC (2015) Gut microbiota mediate caffeine detoxification in the primary insect pest of coffee. Nature Communication 1 (2): $1-8$.

[5] Raina HS, Singh A, Popli S, Pandey N, Rajagopal R (2015) Infection of bacterial endosymbionts in insects: A comparative study of two techniques viz PCR and FISH for detection and localization of symbionts in Whitefly. Bemisia tabaci. PLoS ONE 10 (8): e0136159. doi:10.1371/journal. pone. 0136159 .

[6] Marino YAC, Ospina OE, Rodrigues JV (2018) High diversity and variability in the bacterial microbiota of the coffee berry borer (Coleoptera: Curculionidae), with emphasis on Wolbachia. Journal of Applied Micorbiology 125 (2): 528-543.

[7] Berlitz HD, Grosch W, Schieberle P (2009) Food Chemistry. Springer Berlin, Heidelberg.

[8] Kasana RC, Salwan R, Dhar H, Dutt S, Gulati A (2008) A rapid and easy method for the detection of microbial cellulases on agar plates using Gram's iodine. Current Microbiology 57: 503507. 
[9] Rautela GS, Cowling, EB (1966) Simple cultural test for relative celluloytic activity of fungi. Applied Microbiology 14 (6): 892-898.

[10] Apun K, Jong BC, Salleh MA (2000) Screening and isolation of a cellulolytic and amylolytic Bacillus from sago pith waste. The Journal of General and Applied Microbiology 46: 263-267.

[11] Purwadaria T, Marbun PA, Sinurat AP, Ketaren PP (2003) The comparison of cellulase activities from bacteria and molds isolated from termites. Jurnal Ilmu Ternak dan Veteriner 8(4): 213219.

[12] Jutono J, Soedarsono S, Hartadi S, Kabirun S, Suhadi D, Soesanto (1980) Pedoman praktikum mikrobiologi umum untuk perguruan tinggi. UGM Press, Yogyakarta.

[13] Pelczar M, Chan EC (1986) Dasar-dasar Mikrobiologi. Universitas Indonesia Press, Jakarta.

[14] Waluyo L (2004) Mikrobiologi Umum. UMM Press, Malang.

[15] Volk W (1988) Mikrobiologi Dasar. Erlangga, Jakarta.

[16] Swift FR (1963) A hanging-drop technique for general laboratory use. Microchemical Journal 7 (1): 120-136.

[17] Serra B, Zhang J, Morales MD, de Prada GV, Reviejo J, Pingarrón JM (2008) A rapid method for detection of catalasepositive and catalase-negative bacteria based on monitoring of hydrogen peroxide evolution at a composite peroxidase biosensor. Talanta 75 (4): 1134-1139.

[18] Alatawi A, Susilowati A, Hailu H (2015) Biochemical and molecular characterization of food contaminating bacteria isolates from food stall vegetables. British Microbiology Research Journal 5 (5): 405-411.

[19] Socransky SS, Haffajee AD, Bogren A, Hasturk H, Feres M, Lopez NJ (2004) Subgingivalis chronic periodontitis subjects from different geographic locations. Journal of Clinical Periodontology 31: 996-1002.

[20] Madigan MT, Martinko JM, Dunlap PV, Clark DP (2008) Biology of Microorganisms $12^{\text {th }}$ Edition. Pearson, San Fransisco. 
